\title{
Automation and control of water treatment plant for defluoridation
}

\author{
Swati Dubey $^{{ }^{*} \text {, Madhu Agarwal }}{ }^{1}$, A.B. Gupta ${ }^{2}$, Rajeev Kumar Dohare ${ }^{1}$ and Sushant Upadhyaya ${ }^{1}$ \\ Department of Chemical Engineering, Malaviya National Institute of Technology, Jaipur, India ${ }^{1}$ \\ Department of Civil Engineering, Malaviya National Institute of Technology, Jaipur, India ${ }^{2}$
}

\section{(C)2017 ACCENTS}

\begin{abstract}
In recent times, water treatment plants are mainly established to ensure continuous supply of safe and good quality of water. They are mainly concerned for the conservation of water that is achieved by application of automation controls. Various industrial processes are there where water treatment is essential. To manage the productivity, productivity, improving quality of product/service, reducing downtime and operating costs in current sustainable worry requires a practical approach which can subsequently optimize efficiency of the process and available resources. Automation is one of the most effective tools to achieve this. This paper critically focuses on the technical issues of automation control system that can help in the advancement of automation industry with respect to the management level and process effectiveness.
\end{abstract}

\section{Keywords}

Automatic control system, Potable water treatment process, Process control, Present situation.

\section{Introduction}

Water is considered to be one of the physical environments of human being and has a direct bearing on his health. Clean drinking water is a basic human need. The average daily water consumption for a person is of 30 liters/day [1]. In total of $100 \%$ of water available on earth only $0.01 \%$ of the total water of the earth is available for consumption. India accounts for $2.45 \%$ of land area and $4 \%$ of water resources of the world but represents $16 \%$ of the world population [2]. With the present population growth-rate (1.9 per cent per year), the population is expected to cross the 1.5 billion mark by 2050 [3]. Thus need to efficiently manage the available water resources is the most important problem in front of the world. The use of automated systems is an effective way to handle the limited water resources [4]. Present economic and environment concerns require business to take a pragmatic approach to manage productivity, improving quality of product/service, reducing downtime and operating costs [5]. Automation is one of the most effective tools to achieve it $[6,7]$. The developments during the last four decades in on-line instrumentation, computer technology, process understanding and subsequent model development, and control methods have been powerful driving forces for advanced control making automation even more profitable [8].

*Author for correspondence

6
Today computational power is almost "for free". The instrumentation development shows a progress towards smarter sensors with multiple heads, possible to be placed anywhere in the processes [9]. Actuators such as variable speed drives for pumps and compressors make control more flexible. Control engineering today can offer almost any method that the water operator would need [10]. There are several important demand pull driving forces. Regulatory requirements and increased design complexity have simulated further automation control development [11].It is expected that the use of automation controls for the operation and management of wastewater systems will increase in the coming years. Other demand pull driving forces include continued population growth and urbanization leading to increased wastewater load, continued increase in the complexity in the function and capability of wastewater treatment plants, even more stringent regulations and even- stronger economic drivers[12]. The on-going climate change and the associated extreme weather conditions further add to the challenges. This paper critically reviews the development in the automation controls in water treatment plants [4].

Various Standards that are required for the safe drinking water include the following $[13,14]$ : 
- Water should be free from every kind of pathogens that may lead to certain kind of diseases.

- Drinking water should be free from unwanted taste and odour.

- The desirable limit of turbidity in drinking water is less than 1NTU. So, the desirable limit should be achieved.

- Drinking water should be free from residual chloride and it should be at least $0.5 \mathrm{ppm}$.

\section{Role of automation in water $\&$ waste water treatment industry}

Water being a critical utility in many industries (pharma, electronics, power, etc.), it is important to evaluate the benefits of automation on water and wastewater treatment plants.

To comprehend the significance of automation in waste water treatment, there are following examples [15]:

Bottled water Industry \& beverage Industry: If the conductivity and $\mathrm{pH}$ of the treated water are not monitored and controlled, they will not meet the norms specified for packaged / bottled water specified by BIS [16].
Waste water treatment: The key design parameters for efficient wastewater treatment includes monitoring dissolved oxygen (DO) levels during various cycles of operation. In the absence of instrumentation to monitor it, the treated effluent will not be able to consistently meet the discharge norms with respect to $\mathrm{BOD} / \mathrm{COD} / \mathrm{ammonical}$ nitrogen/phosphorous levels [17]. The above examples reflect the necessity for automation of water and wastewater treatment processes, to consistently meet the standards of treatment. As with any project/process/equipment, the criticality of the process (softening for washing pipes or for boiler feed water) will determine the degree of automation.

To monitor the high purity water various kind of automated solutions have been introduced and PLC dosing system is one of the technique that is much advanced from that of the simpler timer based dosing [15].

\section{Principle application of automation system in defluoridation water treatment plant}

The process of water treatment plant is shown in Figure 1.

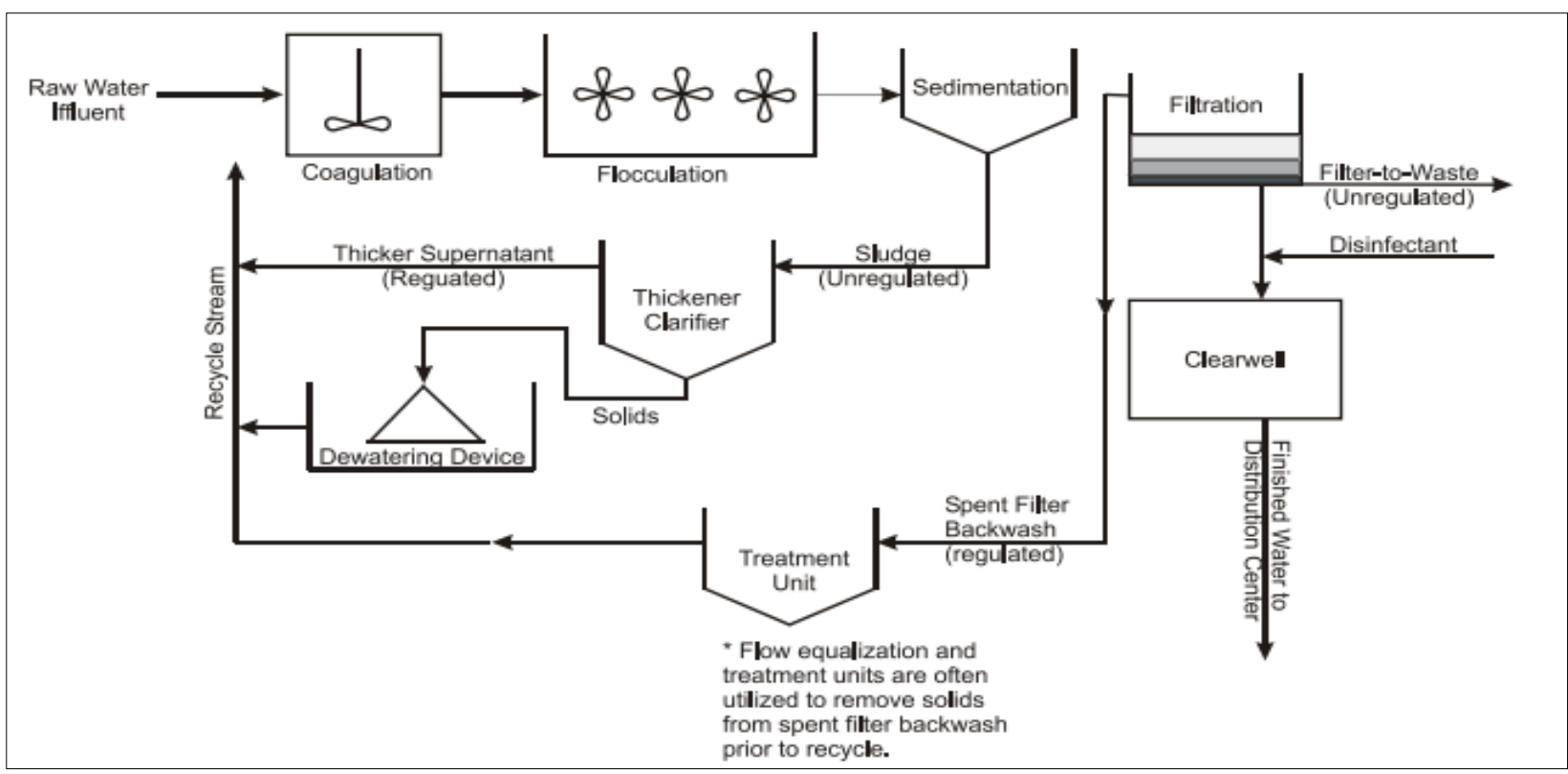

Figure 1 Schematic view of the defluoridation set-up [9]

The process consists of several stages as shown in the Table 1 as follows: (i) Mixing (ii) Coagulation and Flocculation, (iii) Sedimentation, (iv) Filtration, and (v) Disinfection (Chlorination). Firstly, raw water comes into the coagulation tank and after that goes for flocculation where the flocks are formed. Sludge from the sedimentation tank goes into the thickener 
for thickening process and the supernatant goes into the filtration tank where the suspended particles get removed.

Table 1 Process with its possible applications [18]

\begin{tabular}{|c|c|}
\hline Process & Principle applications \\
\hline Mixing & $\begin{array}{l}\text { Provides uniform and rapid } \\
\text { distribution of chemicals and gases } \\
\text { into the water. }\end{array}$ \\
\hline Coagulation & $\begin{array}{l}\text { Coagulation is the addition and } \\
\text { rapid mixing of coagulant resulting } \\
\text { in destabilization of the colloidal } \\
\text { particle and formation of floc }\end{array}$ \\
\hline Flocculation & $\begin{array}{l}\text { Flocculation of destabilized } \\
\text { turbidity and color causing particles } \\
\text { to form a rapid settling floc. }\end{array}$ \\
\hline Sedimentation & $\begin{array}{l}\text { Gravity separation of suspended } \\
\text { solids of floc produced in treatment } \\
\text { processes. It is used after } \\
\text { coagulation and flocculation an } \\
\text { chemical precipitation. }\end{array}$ \\
\hline Filtration & $\begin{array}{l}\text { Removal of particulate matter by } \\
\text { percolation through granular media. } \\
\text { Filtration media may be single, } \\
\text { mixed or multi-layered. }\end{array}$ \\
\hline Disinfection & $\begin{array}{l}\text { Destroys disease causing organisms } \\
\text { in water supply. Methods used for } \\
\text { disinfection are ultraviolet radiation } \\
\text { and oxidation that can be done by } \\
\text { application of certain chemicals } \\
\text { such as chlorine, bromine. }\end{array}$ \\
\hline
\end{tabular}

The process of chemical feeding and handling includes the addition of alum as per the quality of raw water. The process needs online control and monitoring so that the system can work efficiently. To purify water from the particulate matter, filtration is considered to be the most reliable technique.

The process of water treatment consists of several stages for production of pure water. Each stage consist particular equipment's, setup which has defined control functions and the process equipment and control parameters for each stage have been described in Table 2.

The operation of the system can be fully (in Automatic mode) controlled by the Programmable logic controller (PLC) and software. The system components are controlled with the help of the PLC, which communicates with the software. The data sent by the PLC is stored in the server in prescribed formats; this data is used by software for decision making and report generation.
Table 2 Possible control parameters in the process [19]

\begin{tabular}{|c|c|c|}
\hline Process & Equipment & $\begin{array}{l}\text { Control } \\
\text { parameters }\end{array}$ \\
\hline $\begin{array}{l}\text { Chemical handling } \\
\text { and feeding }\end{array}$ & $\begin{array}{l}\text { Solution tank, } \\
\text { Turbulence } \\
\text { channel, Stirrer }\end{array}$ & $\begin{array}{l}\mathrm{pH} \text { and turbidity } \\
\text { testing in } \\
\text { laboratory }\end{array}$ \\
\hline $\begin{array}{l}\text { Coagulation and } \\
\text { flocculation }\end{array}$ & $\begin{array}{l}\text { RCC tank, } \\
\text { bleades } \quad \text { with } \\
\text { gear box, Motor }\end{array}$ & $\begin{array}{l}\text { Mixing of alum } \\
\text { solution into } \\
\text { water and } \\
\text { formation of floc }\end{array}$ \\
\hline Sedimentation & $\begin{array}{l}\text { RCC tank with } \\
\text { tube settler }\end{array}$ & $\begin{array}{l}\text { Suspended } \\
\text { particles are } \\
\text { removed } \\
\text { settling }\end{array}$ \\
\hline Filtration & $\begin{array}{l}\text { Rapid } \quad \text { sand } \\
\text { filter, } \\
\text { pump }\end{array}$ & $\begin{array}{l}\text { Removal of } \\
\text { turbidity and } \\
\text { coarse particle }\end{array}$ \\
\hline Disinfection & Feed valve & $\begin{array}{l}\text { Chlorine dosing } \\
\text { to remove } \\
\text { bacteria and } \\
\text { residual chlorine }\end{array}$ \\
\hline
\end{tabular}

\section{The main contents and methods of process control in potable water treatment}

Dosing control system: Adding drugs is a critical aspect among the entire treatment process. The dosage of drugs directly relates to the quality of effluent water and the cost of production [10]. So, it needs to strongly improve the precision of dosing and reduce the waste of pharmaceuticals [9]. Usually, dosing control system includes coagulation control, pH control and chlorine control [20].

Coagulation control: Recent research proclaimed the streaming current detector (SCD) as an effective method for automatic coagulant dosing control [5]. The SCD selected the micro-electrical characteristics parameter which stood for the essence of coagulant dosing to control the coagulant dosage. SCD is extensively applied in China because it is socially and economically advanced, thereby trouncing the gaps present in existing techniques. The application of this technique is done in three types that are simple single-loop control, cascade control and streaming current feed-forward-single-loop control [21]. The wide research in the field of the flow control of current coagulant dosage resulted in the development of streaming current detector and that lead to the application of this technology in several water plants in Hangzhou, Daqing, Mudanjiang [2]. 
One of the other promising technologies includes Flocculation pulse detection technology that measures the relative change of size in the flocculation process of impurities in water. The main advantage of this technology is that the detection process is not affected by presence of any kind of impurity in water which consequently overcomes the shortcoming of SCD technology. The first application of this technology was done by China to control the high turbidity in Yellow river water in 1992 but because of the high complexion in water, it was not successful and further research needs to be carry out $[22,23]$.
pH Control: Many researchers have considered the clarification stage as the central process of whole water treatment process.

It is here that $\mathrm{pH}$ control strategies will be focused, since $\mathrm{pH}$ is a fundamental factor controlling the performance of the clarification process[24].On the coagulation processes, it may be necessary to use an acid and/or a base for $\mathrm{pH}$ correction purposes to reach the best removal of pollutants[25].However, $\mathrm{pH}$ control with an acid and a base is more complex due to the multi-actuator set-up and also the bi-linear effects caused by differing solution strengths. The control strategy for $\mathrm{pH}$ control is shown in Figure 2.

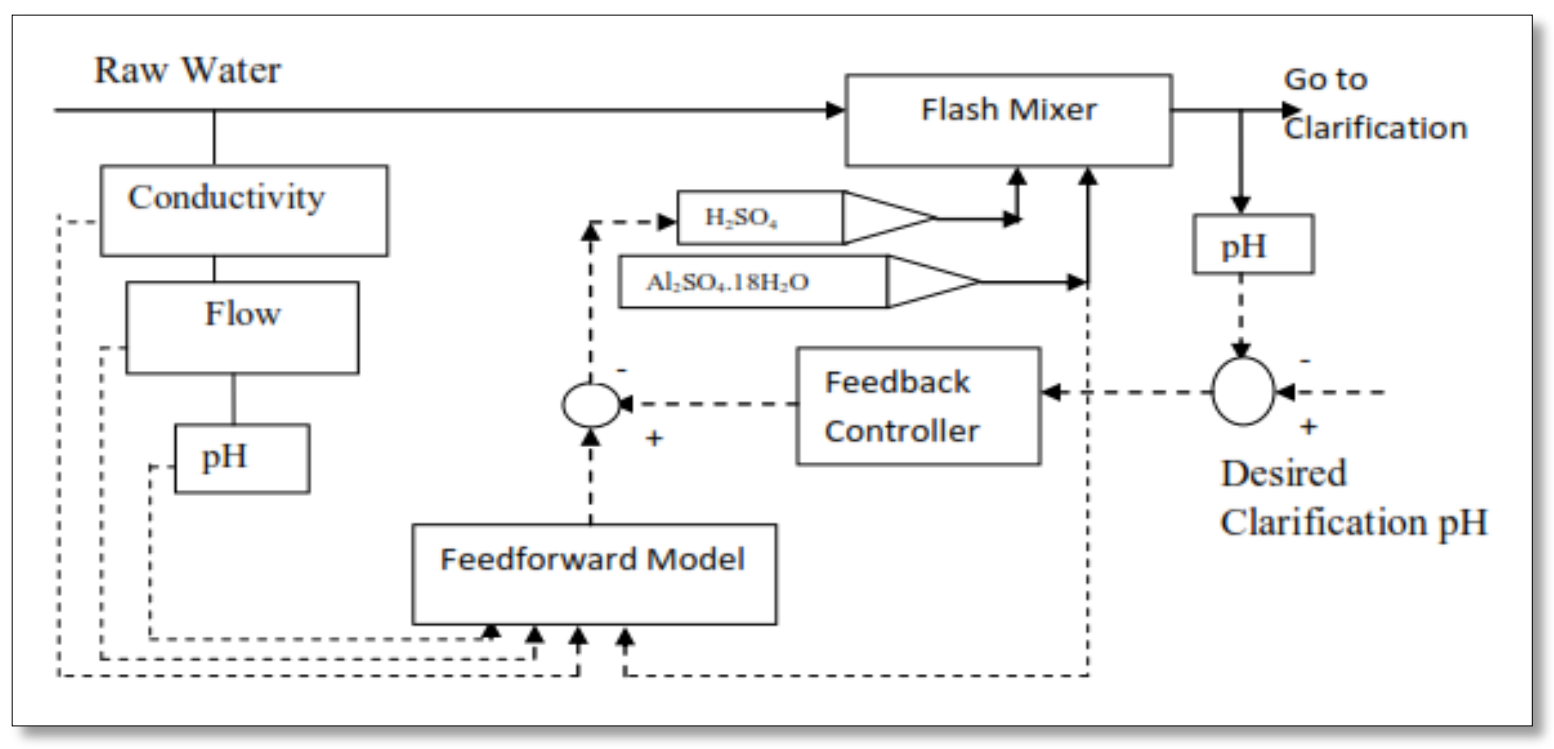

Figure $2 \mathrm{pH}$ control strategy [25]

In the above system, raw water and other chemicals get mixed in the flash mixer and the $\mathrm{pH}$ is measured by the feedback controller and the desired clarification is adjusted accordingly. Conductivity, flow rate and $\mathrm{pH}$ of raw water are controlled by the feed-forward model.

Sedimentation control system: Sedimentation includes deposition of settle floc loaded with fluoride, turbidity, pathogens and other impurities under the effect of gravity [26]. To increase the efficiency of the process, chemical coagulation and flocculation is done before which ultimately results in formation of bigger flocs that enhances the settling process [27]. In the process of sedimentation control, sludge is controlled in sedimentation tank by controlling the sludge volume, sludge cycle and sludge process through the application of mud drainage equipment [25]. Utilization of this equipment is very much beneficial in terms of reducing water consumption and energy consumption in water plant operation and also results in high water quality. Nowadays, PLC which is based on the principle of law of deposition, sludge level is used to attain the control sludge in sedimentation tank. PLC control system is composed of host computer, PLC, Suction Pump Control, Fault Alarm and so on [28].

\section{Conclusion}

Successful process control requires maintenance and knowledge personnel. With automation, routine operator decisions are less critical but effective routine maintenance and the availability of competent personnel for operating emergencies are needed. To ensure such competency at small plants, the implementation of the micro-processor control 
projects would be achieved through the use of private consulting firms which have an interest in operating treatment plants as an offered service. The development had led to the automation system developing of intelligent, decentralized, network, and further promoted the information system to be established in integrated enterprise of control and management.

\section{Acknowledgment}

None.

\section{Conflicts of interest}

The authors have no conflicts of interest to declare.

\section{References}

[1] Ahluwalia IJ, Munjee N, Mor N, Vijayanunni M, Mankad S, Lall R, et al. Report on Indian urban infrastructure and services. Ministry of Urban Development, Government of India, New Delhi. http://icrier. org/pdf/FinalReport-hpec.pdf. Accessed 12 August 2015.

[2] http://www.fc100.org/wp-content/uploads/ 2014/ 04/ Improving-Florida\%E2\%80\%99s-Water-SupplyManagement-Structure-Ensuring-and-SustainingEnvironmentally-Sound-Water-Supplies-andResources-to-Meet-Current-and-Future-NeedsSeptember-2003.pdf. Accessed 12 August 2015.

[3] http://www.ctara.iitb.ac.in/water/references/pws/CHP EEO_PWS_operationsmaintenance_manual.pdf. Accessed 23 December 2015.

[4] Haimi H, Mulas M, Vahala R. Process automation in wastewater treatment plants: the finnish experience. EWater Official Publication of the European Water Association, EWA. 2010.

[5] Qing S, Sheng Z, YunW. Automation control system design and application of fault-tolerant technology in water plan, Microcomputer Applications. 2006; 22(4).

[6] Adgar A, Cox CS, Böhme TJ. Performance improvements at surface water treatment works using ANN-based automation schemes. Chemical Engineering Research and Design. 2000; 78(7):102639.

[7] LingxiaW. Application of automatic control system in water purification process. Management \& Technology of SME. 2008.

[8] Zhi X. Water cleaning automation control system in water plants. Modern Machinery. 2003; 3:019.

[9] Xia RL, Liu LS, Yang GL, Wang DW. A numerical simulation for setting velocity of supernatant-sediment interface during yellow river sediment flocculation. International Journal of Digital Content Technology \& its Applications. 2012; 6(17). 171-84.

[10] Guohou L, Qigao F. The automatic control system of dosing process for tap water. Process Automation Instrumentation. 002; 23(2): 60-1.

[11] Li Y, Chen J. The waterworks' automatic management and control system based on LonWorks. Modern Electronics Technique. 2006; 8: 95-7.
[12] Min Y, Zhangrong T, Yi L. Technical Management of Waterworks. Chemical Industry Press; 2005 China, 276-278.

[13] https://law.resource.org/pub/in/bis/S06/is.10500.2012. pdf. Accessed 23 December 2015.

[14] Andhare SL, Palkar JP. SCADA a tool to increase efficiency of water treatment plant. Asian Journal of Engineering and Technology Innovation. 2014; 2(4):714.

[15] Burali YN. PLC based industrial crane automation \& monitoring. International Journal of Engineering and Science.2012; 1(3):1-4.

[16] Bishop S. Use of the streaming current detector at langsett water-treatment works. Water and Environment Journal. 1992; 6(3):1-9.

[17] Sanamdikar ST, Harne KR. Advanced method for sewage water treatment. International Journal of Advanced Technology in Civil Engineering. 2012; $1(2), 94-8$

[18] http://www.ieiknowledgepark.com/techpaper/automati on.pdf. Accessed 23 December 2015.

[19] Ratnaweera H, Fettig J. State of the art of online monitoring and control of the coagulation process. Water. 2015; 7(11):6574-97.

[20] Rodriguez-Mozaz S, Lopez de Alda MJ, Barceló D. Picogram per liter level determination of estrogens in natural waters and waterworks by a fully automated on-line solid-phase extraction-liquid chromatographyelectrospray tandem mass spectrometry method. Analytical Chemistry. 2004; 76(23):6998-7006.

[21] Lianpeng S, Guozhong H, Guibai L. Application of streaming current forward feed-cascad control system. Journal of Harbin University of Civil Engineering and Architecture. 2001; 34 (2), 125-7.

[22] Liu Y, Zhou J. A novel electro sorption method for circulating cold water treatment. International Journal of Advancements in Computing Technology. 2012; 4(21):288-94.

[23] Liu H, Rong Q, Xu L, Zhang Y. Application of automatic control system in water plant in china. Journal of Convergence Information Technology. 2013;8(5). Lind C. Coagulation control and optimization: part two. Public works. 1994; 125(12):32-3.

[24] Sanamdikar ST, Harne KR. Advanced method for sewage water treatment. International Journal of Advanced Technology in Civil Engineering. 2012; $1(2), 94-8$.

[25] Kawamura S. Integrated design and operation of water treatment facilities. John Wiley \& Sons; 2000.

[26] O'Melia CR. Coagulation and sedimentation in lakes, reservoirs and water treatment plants. Water Science and Technology. 1998; 37(2):129-35.

[27] Hunt KJ, Sbarbaro D, Żbikowski R, Gawthrop PJ. Neural networks for control systems-a survey. Automatica. 1992; 28(6):1083-12.

[28] Yu S, Xu X. An input and output monitoring system for FPGA-based hardware PLC. International Journal of Engineering \& Industries. 2012; 3(1): 34-44. 


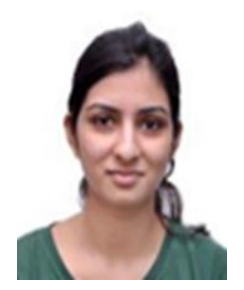

Swati Dubey is $\mathrm{PhD}$ scholar in Department of Chemical Engineering, Malaviya National Institute of Technology (MNIT), Jaipur. She is currently working on Fluoride removal from coagulation technique. She is also a member of IIChE (Indian Institite Of Chemical Engineers). She is the author/co-author of over 6 scientific papers including communications in national and international conferences. Email: swatidubey2021@gmail.com

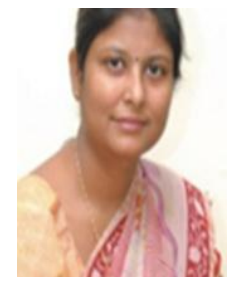

Madhu Agarwal is Assistant Professor in Department of Chemical Engineering, Malaviya National Institute of Technology (MNIT), Jaipur. She received her $\mathrm{PhD}$ in Chemical Engineering from MNIT, Jaipur. She is the author/co-author of over 38 scientific papers with 128 citations including communications in national and international conferences. Her research interests are in the areas of biodiesel, modeling \& simulation, water treatment, adsorption.

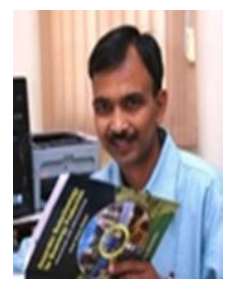

A.B Gupta is Professor in Department of Civil Engineering, Malaviya National Institute of Technology (MNIT), Jaipur. He received his $\mathrm{PhD}$ in Environmental science engineering from IIT, Mumbai. He is the author/coauthor of over 103 scientific papers with 1126 citations including communications in national and international conferences. His research interests are in the areas of Environmental Engg., Environment; Health, Biological Waste Treatment, Env. Modeling, Bioprocess Engineering, Wastewater Treatment

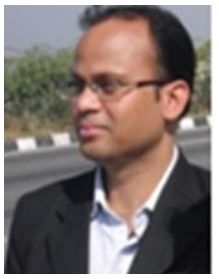

Rajeev Kumar Dohare is Assistant Professor in Department of Chemical Engineering, Malaviya National Institute of Technology (MNIT), Jaipur. He received his $\mathrm{PhD}$ in Chemical Engineering from MNIT, Jaipur. $\mathrm{He}$ is the author/co-author of over 28 scientific papers with 18 citations including communications in national and international conferences. His research interests are in the areas of Modelling and Simulation, Advanced and Intelligent Process control, Fluid Mechanics, and Liquidliquid Separation.

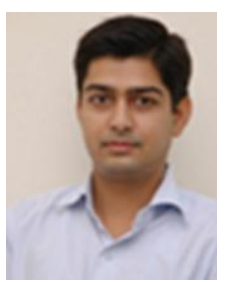

Sushant Upadhaya is Assistant Professor in Department of Chemical Engineering, Malaviya National Institute of Technology (MNIT), Jaipur. He received his $\mathrm{PhD}$ in Chemical Engineering from MNIT, Jaipur. He is the author/co-author of over 18 scientific papers with 32 citations including communications in national and international conferences. His research interests are in the areas of Mathematical Modeling, Desalination, Transport Phenomena, Advance Separation Process, Polymer Processing. 